\title{
CONCUPISCÉNTIA: UNDERSTANDING HUMAN NATURE THROUGH BONAVENTURE AND KAROL WOJYTLA
}

\author{
Joshua Cedric A. Gundayao \\ University of the Philippines, Philippines
}

\begin{abstract}
In the Medieval Era, Christian thinkers try to establish the two-fold concept of human nature - man on his original stature and man after the effect of malum through peccatum. The effect of malum can be seen on the effect of concupiscéntia to man's nature, particularly on man's desire for things. This article used Bonaventure's philosophy to represent the medieval concept of concupiscéntia and how this notion continues to exist in relation to human nature in the contemporary era, as seen in the philosophy of Karol Wojtyla. To facilitate the discussion, the author presented the following points: firstly, human nature in general. Secondly, the philosophy of Bonaventure regarding concupiscéntia is tackled. Thirdly, Karol Wojtyla's concept of concupiscence as found in Love and Responsibility is presented, and lastly, the researcher pointed out the convergence and some possible objections to the claim. This paper not only presented concupiscéntia from the perspective of Bonaventure and Wojtyla but also demonstrated that there is continuity in Christian philosophy in discussing human nature, particularly its notion of concupiscéntia.
\end{abstract}

\section{INTRODUCTION}

God and man are the two main ideas that were undertaken by thinkers during the medieval era. On the one hand, there is the concept of God that, despite its ineffability, continues to manifests and unfolds Himself in the course of history. On the other hand, man's nature, as scrutinized in medieval philosophy by most scholastics, presents himself as someone who is always in relation to God. As history develops, the Church is called to discern and reflect within herself how she can answer to the signs of times that push her on all sides. Ressourcement and aggiornamento are two German words that were mostly used during the Second Vatican Council. These two movements aim to bring renewal to the Catholic Faith by reading the signs of the times and responding to the need of men by presenting faith through new expressions and approaches (aggiornamento) through the constant return to the authoritative sources and eternal truths that Church holds vital and necessary (ressourcement). 
Such a call for renewal is not only true to theology but also to Christian philosophy. As Christian philosophy heeds the call for renewal in anthropology as man exposes himself or herself to a changing world, Christian philosophy always goes back to sources, the anthropology which can be traced back to the scholastics down to church fathers.

Through Aristotle, ancient philosophy introduced man as a rationis animalis a being capable of rationality by virtue of its rational soul, which makes him or her different from other beings. When the medieval ages entered history, it reinvented Aristotle's rationis animalis by postulating that man is first and foremost an imago et similitudo Dei; but with all the likeness that man possesses, he or she is corrupted by a fallen nature. As Christian Philosophy adapts to the changing world, its conception of anthropology also develops, but it does not totally depart from the original concept of anthropology as explained by medieval philosophers.

This paper proves that there is continuity in the discussion of anthropology, particularly on the concept of concupiscéntia in Christian Philosophy. In proving the point, the researcher used Bonaventure's philosophy to represent the medieval concept of concupiscéntia and explained how this notion continues to exist in relation to human nature in the contemporary era, as seen in the philosophy of Karol Wojtyla. The researcher opted to used Bonaventure in discussing Human Nature side-by-side with Wojtyla since the similarities of the two thinkers are rarely sought. This paper discussed that Bonaventure's concept of concupiscence is the same as Wojtyla's concept of concupiscence. Hence, the entire tradition of Christian Philosophy from the Medieval Era down to contemporary Christian Thinkers shares the common notion of concupiscence, anchored in the truth found in Christian Philosophy. To facilitate the discussion, the author presented the following points: first, human nature in medieval ages as seen in Bonaventure's philosophy; second, the philosophy of Bonaventure regarding concupiscéntia; third, Karol Wojtyla's concept of concupiscence as found in Love and Responsibility; and lastly, the convergence and some objections regarding concupiscéntia in the philosophy of Bonaventure and Wojtyla.

\section{HUMAN NATURE IN BONAVENTURE}

Bonaventure is a Franciscan thinker whose philosophy is deeply anchored in theology as, during the medieval ages, philosophy and theology are most of the time intertwined. During his time at the University of Paris, which is the place to be in the medieval era if one wanted to venture into philosophy and theology, he is one of the prominent scholars alongside Thomas Aquinas, although the former did not enjoy the luxury of time since his stint was cut short when he was elected as the Minister General of their order. In Late Medieval Mysticism, Ray C. Petry $(1957,127)$ claimed that Bonaventure's thoughts and philosophy are products of the prevailing thought during the medieval ages, a synthesis of different thinkers and individuals that he encountered at the University of Paris and as a Franciscan friar. His philosophy is heavily laden with the influence of Pseudo-Dionysius, Augustine, Plato, and Aristotle, whose influence dominates medieval philosophy, particularly medieval Christian philosophy. 


\section{Bonaventure's Anthropology}

The conception of man as an imago et similitudo Dei is quite popular, if not all, to most Christian philosophers in the medieval era. Like most Christian philosophers during his time, Bonaventure has a two-fold conception of man: the pre-lapsarian status and the post-lapsarian status about the corruption and distortion that happened to man due to fall. In Breviloquium, Bonaventure $(2013,90)$ postulated that in the prelapsarian condition, God made man, a rational creature, with the body (caro) and soul (mens) - the body being the corporeal substance, while the soul constitutes the spiritual substance. Man is a composite of body and soul. The idea of being an imago et similitudo Dei in Bonaventure can be explicitly found in his conception of man as a being. In Itinerarium Mentis in Deum, Bonaventure $(2002,83)$ stated that "the soul itself is an image of God and a similitude so present to itself and having God so present to it that it actually grasps God and potentially 'has the capacity for God and the ability to participate in God'. As an image of God, it is possible for a man to ascent into God by reflecting his or her own soul - since the soul is a vestige of God - in order for man to fulfill his or her task to be in ecstatic union with God. Moreover, man is originally made standing upright by God. In the introduction to Bonaventure's Writings on the Spiritual Life, F. Edward Coughlin, O.F.M. (2006, 9) postulated that for Bonaventure, "the physical uprightness of the body's carriage was to bespeak the rectitude of mind. The body is united with the soul as its perfective principle so that it might move toward and attain the blessedness for which it was made".

In Breviloquium, Bonaventure $(2013,84-85)$ claimed that Man as a rational soul, God created man ex nihilo, and bestowing eternal life, God made the human soul immortal. Hence, the imago Dei is explicitly seen in his or her soul, which is immortal like God. The human soul, as an imago Dei, possesses threefold powers, namely memoria, intelligentia, and voluntas. Following The Confessions of Augustine (2014, 207) who stated that "mind is even memory itself," for Bonaventure, the soul through memoria allows the human person to retain things from the past, even the immutable truths regarding reality, and represent it when needed. Whereas intelligentia, in Itinerarium Mentis in Deum of Bonaventure $(2002,85)$ is the power of the soul to understand propositions and inferences through the understanding of meaning by grasping it into the truest sense possible. The object of intelligentia is truth. It is directed towards the truth so that little by little, man can ascent to the Creator, who is the Supreme Truth. While voluntas is related to the appetite of the human person, it pertains to man's capacity for choice exemplified through deliberation, judgment, and desire. In The Psychology of Love According to St. Bonaventure, Robert P. Prentice $(1992,32)$ mentioned that the appetite is always directed towards the good; the soul seeks good and has the tendency towards any good. Voluntas is propelled by the desire to do something in the presence of a good. Since man by nature desires to be perfected, he or she is drawn towards the good since it is through the good that man will attain perfection. While desire is always directed towards the summum bonum, the desire for the other goods is permissible, given that it should and must be anchored and in pursuit of the summum bonum. Bonaventure $(2002,89)$ clearly stated that the notion of the summum bonum is impressed on anyone since without which man cannot measure things in terms of likeness to this highest good, which is God Himself. Man desires the 
lower good due to its relation to the summum bonum, without which the lower good loses its goodness since it only participates in the goodness that the summum bonum exemplifies.

\section{Fall of Man}

Man, as a rational creature, was imperfect despite being an imago et similitudo Dei since he or she is created out of nothing. In Breviloquium, Bonaventure (2013, 100) discussed that as creatio ex nihilo, man could "fail to act out this intrinsic relationship with God. It instead (can) act for itself rather than for God". Man can choose to do what he or she wants in contrast with the summum bonum. In his book Bonaventure, Christopher Cullen $(2006,135)$ mentioned that despite possessing the voluntas, man's capacity is still fallible and capable of failing to adhere to the summum bonum. In fact, in the biblical narrative of the fall of man, the first human fell into sin by the wrong use of voluntas; man failed to act for God and ended up acting for himself by choosing to eat the forbade. The first human opted, by virtue of his or her freedom, to violate the order of love: to love and desire everything in relation to the summum bonum. This violation of the order of love resulted in peccatum or sin that, in return, corrupted man giving rise to his or her post-lapsarian nature. Bonaventure $(2013,114)$ stated that peccatum does not proceed from a well-ordered will but from a disordered will that is not yet stabilized by glory. Peccatum is not also a product of choosing evil since voluntas is always geared towards the good for only what is good is what is desirable for man. Rather, it is a product of choosing the lesser good apart and, in comparison, to the summum bonum. In Simply Bonaventure, Ilia Delio $(2011,75)$ explained that peccatum is freedom gone awry, in contrast to the original freedom of man, which is oriented towards God; since man chooses other things instead of choosing God, man disregard the Summum bonum for the sake of a lower good. However, voluntas should not be seen as utterly evil since it can choose good, and the soul cannot be evil but only corrupted by it, nor is it perfectly good since it can fall into evil. Bonaventure $(2002,51)$ narrated in Itinerarium Mentis in Deum that

... turning away from the true light to the changeable good, the first human was bent over through a personal fault, and the entire human race became bent over by original sin, which infected human nature in two ways. It infects the mind with ignorance and the flesh with concupiscence.

As a result of peccatum, man's being is infected by the corruptive influence of malum. Hence, in Breviloquium, Bonaventure $(2013,99)$ stated that malum "is not a kind of essence but a defect and corruptive influence, which contaminates measure, form, and order in the created will." It is a privatio boni. Despite its nature as something that opposes good, malum has no existence and origin except on the good since it is its corruption; without the good to be corrupted, malum will not exist. Malum has corrupted man as a result of failing to do his or her goal: to accomplish everything he or she has to do with God as his or her source of action and end according to God's 
norms. Hence, man chooses evil indirectly, whenever he or she forsakes the summum bonum for the lower good.

Malum is not simply a corruption or defect in measure, form, and order of things. In addition, Bonaventure $(2013,125)$ identified malum as the "withdrawal from the First Principle." It is the withdrawal that, in return, causes the corruption and disorder within man. As an illustration, if a man chooses the mutable good apart and above the summum bonum, he or she is withdrawing himself or herself from the primum principium since the summum bonum et primum principium is no other than God. The corruption in order of things leads to the choice of mutable good independent of the summum bonum. Malum culpae is the one that corrupts man primarily through a voluntary withdrawal from God through the choice of immutable good.

In the pre-lapsarian status, man has the capacity to grasp and participate in God, but due to malum, man is now ignorant by having an unclear vision of God's vestiges and gets easily attracted to the lower goods instead of participating in God due to concupiscéntia. Bonaventure agrees with Augustine that after original sin, man is fallen and condemned being before God whose post-lapsarian nature was passed on to all humanity. In A History of Mediaeval Philosophy, Battista Mondin (1991, 110) postulated that after peccatum, the free will and the powers of the soul in general, particularly intelligentia and voluntas, suffer the effects of malum and the difficulty of resisting concupiscéntia.

\section{BONAVENTURE AND CONCUPISCÉNTIA}

It is the imago Dei in man that was primarily corrupted through distortion by malum. This distortion can be explicitly seen in its effect on man's freedom, as realized in the state of concupiscentia. Simply put, Ilia Delio $(2011,78)$ postulated that "once the image was distorted, so too was human freedom." With a distorted voluntas, man continues to seek the good that he lost in the beginning. However, man is now confused about which to choose when face with different types of good as he is enveloped in darkness. For this reason, man now has the difficulty of discerning which things should be pursued and which should not be. In The Hidden Center: Spirituality and Speculative Christology in St. Bonaventure, Zachary Hayes, O.F.M. (2000, 22) pointed out that corrupted by malum and suffering from concupiscéntia, man is restless by the striving unendingly to seek the good that was lost due to the fall.

Concupiscéntia results in a disordered will. Hence, Ilia Delio $(2011,77)$ advanced the idea that due to concupiscence, there is now a disorder inside and outside the human person. Within man, there is the dilemma of having the tendency to choose the lower good; outside man, there is the predicament of how to discern which good should be sought. In both cases, man is now positioned in a disordered situation inside and outside himself or herself. Hence, Zachary Hayes, O.F.M. $(2000,22)$ pointed out that due to concupiscence, "our power to love is distorted and our relation to the world is profoundly sick."

Concupiscéntia is manifested in man's desire for the good. In the introduction of Writings on the Spiritual Life, F. Edward Coughlin O.F.M. (2006, 31) stated that it is the desire for things that are not in conformity with the highest goodness. This 
inconformity happens not only when man pursues the good apart from the summum bonum but also when man opted to choose things apart and not in the pursuit of the summum bonum as its final end. It is the disordered affectivity due to the post-lapsarian nature that inclines man to choose otherwise. Due to disordered affectivity, man has the tendency of natural desires and appetites to pursue their own objects despite the proper order of reason, which points out to the summum bonum as the end or goal of all action.

According to Illia Delio $(2011,79)$, in his or her fallen nature, man is now immersed in the things of the senses and has the tendency always to pursue it. Concupiscéntia inclines man to always seek the good in an unqualified sense of the good. Due to ignorance, he or she suffers from the fall in addition to a disordered will; man has the tendency to chase all the goods that he or she encounter in the hope of regaining what the first man had lost at the beginning of time. For F. Edward Coughlin O.F.M. (2006, 35), it is "the distorted desire for lesser goods and the temptation to rise above one's humble estate as a human being (pride)" that also propels man to seek lesser goods. Man does not only seek good simply to regain what was lost; the desire is also anchored on man's desire to regain also the original stature that was enjoyed before.

In man, there is a kind of entitlement that tries to seek, through his or her efforts alone, to repair and find what was broken and lost. This desire to find that thing that would appease his or her yearning for what was lost is most commonly manifested in the desire for pleasure. It is found in pleasure since it is the most accessible and more appealing kind of 'good' that the human person encounters. F. Edward Coughlin O.F.M. $(2006,33)$ further explained that in the realm of pleasure, man principally manifests this desire in the quest for carnal pleasure. Concupiscéntia is the distorted or corrupted desire of the human person. However, desire should not be seen negatively since in the original stature of man; desire is originally upright. Hence, desire is not synonymous with concupiscéntia, but concupiscéntia is a type of corrupted desire.

Carnal pleasure is not limited to the desire for sexual pleasure; this type of pleasure also involves the desire for savory food, fine garments, and luxurious desires, or anything that pleasures the senses. However, in the contemporary period, this desire for carnal pleasure is explicitly manifested in man's desire for sexual pleasure. Due to the desire to regain what the identity man had lost, he or she succumbs to sexual pleasure as if that kind of activity rebuilds his or her identity. Instead of renewing within oneself the identity that was distorted, man, in his or her pursuit of sexual pleasure, embodies new identity as if his or her nature as a person is only limited to sexual activity for the reason that this activity is the one that satiates the desired man needs. F. Edward Coughlin O.F.M. (2006, 33) also noted that concupiscéncia propels man to search for sensual satisfaction, which he or she finds in carnal pleasure.

\section{KAROL WOJTYLA AND CONCUPISCENCE}

Karol Wojtyla is a $20^{\text {th }}-21^{\text {st }}$-century philosopher whose philosophy discusses the truths regarding the human person by dialoguing Christian Philosophy with contemporary thinkers. He became pope from 1978 to 2005 . Through his papacy, he 
addressed the problems of the contemporary period through theology and philosophy. As a Christian philosopher, he focused on personalism and Christian humanism, particularly in discussing the human person and the notion of love. As a product of philosophical tradition, he tried to appropriate Christian teachings thru his philosophy by means of the influence of philosophers such as Thomas Aquinas, Augustine, Max Scheler, Rene Descartes, and Immanuel Kant.

\section{Union Between Man and Woman}

In Love and Responsibility, Karol Wojtyla (2013, 129), particularly on his discussion of sex, pointed out that love transcends sexual relationship from mere intercourse between persons of the opposite sex because of love, the "relation of the subject to the objects yields to the union of persons, in which a man and a woman have the sense that they constitute in a sense, one common subject of action." In sex, the mere relation due to the activity becomes the union of two persons. This union can be characterized by the openness of both persons that makes the union possible. In the Theology of the Body for Beginners: A Basic Introduction to Pope John Paul II's Sexual Revolution, Christopher West $(2004,21)$ mentioned that "human sexual union is not merely a biological reality. It is also a spiritual and theological reality. The human body is meant to reveal and participate in the spiritual mystery of divine love." Hence, to be in one flesh in sexual intercourse is not only to be connected to the level of the physical body, but it is a sacramental expression of the communion and union between two persons. The union between persons transcend the sexual act of bodily union and human love as an experience of the experience of divine love.

Devoid of concupiscence, the original experience of man's nakedness is that one that is without shame. Christopher West $(2004,22)$ further stated that "lust (selfseeking sexual desire) had not yet entered the human heart. Hence, our first parents experience a total defenselessness in each other's presence because the other's look posed no threat whatsoever to their dignity." They freely open themselves to each other to make the union and experience of love possible. Opening oneself is easy because man knows that the other would not violate him or her since everything is an expression of love. Facing each other, both man and woman unite everything with each other in the union of love. In Love and Responsibility, Karol Wojtyla $(2013,129)$ further stated that man and woman's "wills unite through the fact that they want one good as an end, while their affections unite through the fact that they together experience (przezywal) the same values." Through the union of man and woman and having one goal, sexual intercourse is transcended into a union. Hence, it is no longer sheer sexual intercourse that a man and a woman experience but a union of two different individuals possessing one good goal as an end of the union. Karol Wojtyla $(2013,129)$ added that "the deeper and more mature the union is, the more a man and a woman have the sense that they constitute, in a sense, one subject of action". Nonetheless, despite the exclusive union between a man and a woman, their difference as two different beings and two different subjects is not consumed or diminished due to the union that takes place.

Man is endowed by freedom; because of this freedom, man can express love, and without freedom, love is impossible. Christopher West $(2004,20)$ explained that 
man, first and foremost, is called to a 'covenant of love with God', and upon experiencing divine love, man longs with the entirety of his being to share this love with another person similar to its being. This desire to share love with another person is embedded in man's very being, which can also be seen in man's sexual desire. Christopher West $(2004,22)$ postulated that "God created sexual desire "in the beginning" to be the very power to love as he loves - in a free, sincere, and total gift of self." Originally, in the pre-lapsarian status of man, sexual desire's original intention is to propel man towards the desire to love, which is realized in the 'sexual union' of a man and a woman. In the state of innocence, man sees the other person is not a mere object of desire but as a subject.

Love is the total self-donation to the other person. In the Theology of the Body, Karol Wojtyla (15:1) or Pope John Paul II (1997) explained that the original meaning of love, therefore, "is the body's power to express love: precisely that love in which the human person becomes a gift and-through his gift-fulfills the very meaning of his being and existence." To love is to become a gift that offers the entirety of one's person to the other in sexual union. In relation to the rest of creation, unlike animals, man is not determined by bodily instinct. Man rationally offers himself or herself to the other person, in openness, in every activity of love or union.

\section{Concupiscence}

Man as a person and as an object of love should always be treated as a person and never as a means towards an end. However, Karol Wojtyla $(2013,130)$ mentioned that sex, which is "manifested in the body, and which as a property of the body falls under the senses, creates a possibility of concupiscence." It can be experienced primarily when the body is seen as a mere object that can be used. Concupiscence is an effect of the fallen nature of man, which distorts a lot of things within man, including his or her attitude towards sexual union. Due to sin manifested in the concupiscence of the flesh, man's experience and understanding of sex became heavily distorted, not only because man sees the sexual experience as something immoral but also because man sees sex as an end in itself. In his book Aquinas and the Theology of the Body, Thomas Petri OP discussed that in the state of innocence, the desire for sensible pleasure is harness by reason, but due to fall that leads to the distortion in the faculties of man, concupiscence enters the realm of sensible pleasures.

In Love and Responsibility, Karol Wojtyla (2013, 133) mentioned that "the concupiscence of the flesh goes in the direction of finding "an outlet." And after having found it, the entire relation to the object of desire breaks off." The difficulty arises in connection with the problem of love and with the relations between persons since, due to concupiscence, sexual desire becomes only a thing that needs to be satiated, and when it is already appeased, the desire also fades away. Wojtyla $(2013,133)$ stressed that in a relationship driven by concupiscence, man is oriented to the body as a possible object of use that would satisfy him or her; the relationship between persons is viewed in a utilitarian sense, a consumption-oriented way. What happens is that the other person is only limited to his or her body, whose main task is to satiate the sexual desire. According to Thomas Petri $(2016,229)$, Thomas Aquinas would agree with Wojtyla 
since, for him, "original sin is an inordinate disposition arising from the destruction of the harmony which was essential to original justice." In the case of concupiscence, man has a distorted expression of sexual desire that resulted in viewing the other person as a mere object.

'Bodily love' in Wojtyla manifests the concupiscence of the flesh since its value is not the same as the love of a person that love, in general, should possess. Karol Wojtyla $(2013,132)$ mentioned that in bodily love, "the concupiscence of the flesh replaces the object of love, which is the person, but only to the "body and sex" of a concrete person, precisely "as a possible object of use." Here, the value that is supposed to be found in the person is misplaced and seen only on the body of the other person and on the activity of sex. Instead of aiming for the other person per se as the source of value of love, a man finds value in body and sex alone. Karol Wojtyla (2013, 130) further added that "desire differs from the interest or absorption of sensuality in the sexual values "reaches" the subject, whereas, in the case of desire, the subject clearly turns towards the value." However, man is not doomed to remain within bodily love alone because man is not simply composed of a body, but also of spirit. As a result, man is capable of transcending this bodily love into spiritual love, which is seen in spousal love. In spousal love, which necessarily leads to marriage, man is able to remedy the concupiscence, so to speak; insofar as in spousal love, disinterested love manifests. As Wojtyla affirms the twofold end of marriage, namely procreative and unitive, he has also highlighted that marriage remedies the concupiscence. Thomas Petri, OP $(2016,55)$, stressed that "the procreation and education of children cannot properly be carried out without the mutual life of the spouses and a remedy for concupiscence."

Christopher West $(2004,28)$ explained that devoid of God's love due to the fall, the desire of man and woman for each other became altogether different. Instead of experiencing desire as an enticement to be a gift to each other, they are drawn by a desire to see each other as mere objects of one's gratification; the giving is now onesided and not reciprocal. Intimacy and sexual intercourse between persons that proceeds from concupiscence are not equated to the union as originally envisioned by Wojtyla. This happens because love is no longer the reason for intimacy and intercourse but mere desire. Karol Wojtyla $(2013,133)$ argued that "concupiscence of the flesh alone is a denial of love of persons, for at their basis lies the directional reaction to "use" - the reaction characteristic of pure sensuality." Instead of being a gift to each other, concupiscence centers on consuming the other person.

Karol Wojtyla $(2013,132)$ postulated that the concupiscence of the flesh is dangerous because it leads to "love" that is not love, and "it evokes amorous livedexperiences on the basis of sensual desire alone". In the amorous lived-experience, the supposed to be an experience of union is replaced by the experience of the other person as a mere object, not of love, but merely of body and sex that satisfies man's desire. Karol Wojtyla (2013, 133) further argued that concupiscence transforms bodily intimacy that should result in the union to mere sexual intercourse. Despite physical union in sexual intercourse, this kind of union will not suffice for it to be called love. He $(2013,133)$ even added that "the concupiscence of the flesh is not a source of the person's love, even though it evokes amorous (erotic) lived-experiences charged with a large dosed of sensual affections." The product of concupiscence, which is sheer 
amorous lived experiences, and sensual affections, does not commensurate with the qualification of love in the strict sense since love is all about the union between persons; anything else falls secondary to this qualification.

\section{CONCUPISCÉNCIA IN BONAVENTURE AND WOJTYLA}

In the face of a changing world that time and again tries to shape and reshape the conception regarding who the human person really is, the tradition of Christian philosophy has shown that it was able to stand different ideologies that attempt to redesign the conception of man, particularly in relation to concupiscence. This is not to imply that Christian philosophy never developed; it means that as Christian philosophy adapts to the changing world, its main teachings remain unchanged. This unchanging tradition is explicitly manifested in Bonaventure and Wojtyla, that despite no explicit connection between the two, the medieval Christian philosophy as exemplified by Bonaventure is still present in the contemporary Christian philosophy as represented by Wojtyla. The discussion of Bonaventure and Wojtyla regarding the human person, particularly on its fallen, is similar because of the following points: first, concupiscence is the effect of the fallen nature of man, second, man suffered from a disordered desire, and third, due to concupiscence, man is inclined to choose the lower good in contrast to the summum bonum.

Concupiscence is the effect of the fallen nature of man. Both Bonaventure and Wojtyla agree that concupiscence distorts the powers of the soul, particularly the will. Due to this, the human person always seeks and pursues the good that he or she encounters despite the uncertainty regarding the good. In the state of innocence, man's stature is upright since it has the capacity to differentiate what should be pursued and what should be avoided. In Bonaventure, due to this concupiscence, man is now blinded in seeing the different goods that confront him or her resulting in the tendency to make the wrong choice in relation to the good. While for Wojtyla, concupiscence is explicitly manifested in the tendency of the human person to choose sex as an end in itself. It is distorted because sex is only part of the union between persons and is not limited to it.

In discussing concupiscence as a kind of disordered desire, Bonaventure and Wojtyla support the idea that after the fall, the human person misplaces his or her desire for what is to be pursued. Since the human person lost its original stature due to the fall, man has the tendency to pursue all the goods he or she encounters, notwithstanding the consequences, in the hope of regaining what was lost due to the fall. This tendency to desire all things in a disordered manner can be seen in Wojtyla's concept of concupiscence since, in his discussion, man now sees the other person as a mere object of desire and not as a subject worthy of love. In the fallen nature of man in Wojtyla, man tends to satiate his or her sexual desire with amorous livedexperiences, which is a denial of love and not oriented towards union, which is the purpose of love.

The medieval claim of man's tendency towards the lower good, as a result of the fall, is still present in contemporary Christian philosophy. Due to fallen nature, instead of aiming for the summum bonum, man has the tendency to pursue the lower 
good for its own sake and not in relation to the summum bonum, which is clear in Bonaventure's philosophy. He even added that in the quest for the good, man ended up satiating his or her desire with sensual pleasure, or with a lower good, since it is a type of good that is easily accessible to the human person. Wojtyla will agree with that claim since, due to concupiscence, man tends to pursue sexual activity by aiming for sex and body per se and not on the mystical and theological union that it will yield. Man tends to satisfy himself or herself with amorous lived-experience instead of a union which is a higher good and leads man towards the summum bonum in relation to sex and body per se which, when pursued as an end in itself, is a lower good and not in relation to the summum bonum.

\section{Objections}

In establishing the concept of concupiscéntia in Bonaventure and Karol Wojtyla, one might think of the following questions or objections:

1. If concupiscence is by nature part of man since he or she inherited it, how come that it is seen as something negative?

2. If desire is natural, how come that concupiscence, since it seems to be also a kind of desire, is undesirable?

To answer the first objection, it is true that concupiscence is natural to man by virtue of it being part of its nature. However, it remains to be undesirable since concupiscence only entered after the fall of man. Originally, concupiscence is not part of man's stature, as seen in the pre-lapsarian anthropology. Since concupiscence only happens in the post-lapsarian nature of man as being part of man's fallenness, this trait is viewed negatively. In addition, concupiscence does not have an existence on its own. As an effect of malum being a corruptive influence to man, concupiscence happens through the exploitation of the good; in this case, through the corruption of man's desire, which is originally directed towards the summum bonum.

In relation to the second objection, one can again look at the difference between the pre-lapsarian and the post-lapsarian stature of man. Concupiscence is undesirable since it is a distorted type of desire. In the beginning, man's desire is directed and always anchored on the summum bonum, but after the fall, this desire was distorted and erroneous to other things. In Bonaventure, desire due to concupiscence is misplaced as a desire for lower good per se and not in the pursuit of the summum bonum. This desire, distorted by concupiscence, was translated to Wojtyla through man's sexual desire. Due to concupiscence, instead of aiming for the union, which would help man reflect regarding the mystical union with God, man's sexual desire is oriented wholly on the desire for body and sex as sexual activity and not part of a union.

\section{CONCLUSION}

Aggiornamento always goes side by side with ressourcement. One cannot simply respond to the signs of the times by adopting all the changes possible without looking at the source as the basis of what should be done and how to respond to certain 
dilemmas that befalls man's consciousness. Like the Church, Christian philosophy adapts to the changing world but does not forsake its core teachings. Its adoption is done through the appropriation of Christian philosophy to the contemporary dilemma that man is facing. As a strong tradition, Christian philosophy was able to uphold its anthropology by presenting man through its two-fold stature, the state of innocence, and after the fall. This chain of thought in Christian philosophy is evident in the philosophies of Bonaventure and Karol Wojtyla. In the tradition of Christian philosophy, man is originally oriented and destined to desire the summum bonum, which is God. However, due to the fall, malum corrupted human nature inducing the influence of concupiscéntia on man. Concupiscéntia distorts man's desire by inclining man to desire the lower good apart and in contrast with the summum bonum. In the realm of sexuality, man finds himself or herself, pursuing sexual desire no longer as a means for the theological and spiritual union between two persons but only for the sake of sexual activity per se and the other person's body as an object of one's desire.

\section{REFERENCES}

Augustine. 2014. The confessions. Translated by John K. Ryan. New York: Image Books.

Bonaventure. 2013. Breviloquium. Translated by Dominic V. Monti, O.F.M.. New York: Franciscan Institute Publications.

Bonaventure. 2002. Itinerarium mentis in Deum. Translated and Edited by Philotheus Boehner, O.F.M. and Zachary Hayes, O.F.M. New York: Franciscan Institute Publications.

Bonaventure. 2006. Writings on the spiritual life. Translated by Girard Etzkorn. New York:

Franciscan Institute Publications.

Christopher Cullen. 2006. Bonaventure. New York: Oxford University Press.

Delio, Ilia. 2011. Simply Bonaventure. New York: New City Press.

Hayes, Zachary, O.F.M. 2000. The hidden center: Spirituality and speculative Christology in St. Bonaventure. New York: The Franciscan Institute.

John Paul II. 1997. The theology of the body: Human love in the Divine plan. Boston: Pauline Books and Media.

Mondin, Battista. 1991. A history of mediaeval philosophy. Bangalore: Theological Publications in India.

Petri, Thomas, O.P. 2016. Aquinas and the Theology of the Body: The Thomistic foundations of John Paul II's anthropology. Washington: The Catholic University of America Press.

Petry, Ray C. 1957. Late medieval mysticism. Kentucky: West Minister Press.

Prentice, Robert P. 1992. The psychology of love according to St. Bonaventure. New York: Franciscan Institute Publications.

West, Christopher. 2004. Theology of the Body for beginners: A basic introduction to Pope John Paul II's sexual revolution. USA: Ascension Press.

Wojtyla, Karol. 2013. Love and responsibility. Translated by Grzegorz Ignatik. USA: Pauline Books \& Media. 